\title{
Mídia-educação no Ensino Médio: por que e como fazer ${ }^{1}$
}

\section{Media-education for High School: why and how to do it}

\author{
Alexandra Bujokas de Siqueira ${ }^{2}$ \\ Mariana Pícaro Cerigatto ${ }^{3}$
}

\begin{abstract}
RESUMO
Embora não seja assunto novo, a aprendizagem sobre mídia é tema que vem ganhando espaço na educação brasileira. Internacionalmente, a promoção da media literacy é prática talvez tão antiga quanto os próprios meios de comunicação. Com a ascensão das chamadas novas mídias, paradigmas educacionais e materiais pedagógicos têm mudado rapidamente, requerendo uma revisão de conceitos e um novo posicionamento dos estudos de mídia no currículo escolar. Neste contexto, o presente artigo apresenta uma proposta de trabalho sintonizada com os paradigmas da mídia-educação inglesa (Hall, Whannel, Buckingham, Kress) e da nova esfera da cultura digital. Partindo de trailers de cinema disponíveis no Youtube, criamos atividades de leitura e escrita em mídia para o Ensino Médio, dentro da área de Códigos, Linguagens e suas Tecnologias, testando tais atividades com 20 estudantes de uma escola da rede pública de ensino de Bauru, Estado de São Paulo. A metodologia consiste em selecionar trailers de filmes populares de gêneros diferentes e criar atividades para desmontar o texto audiovisual, explorar as características da linguagem, pensar nas relações do texto com a audiência e avaliar a aprendizagem possível. Os resultados sugerem que o foco na análise sistemática da linguagem é um caminho produtivo para refletir sobre questões de representação, identi-
\end{abstract}

\footnotetext{
${ }^{1}$ Projeto financiado pela Fundação de Amparo à Pesquisa do Estado de São Paulo (Fapesp), nas modalidades Auxílio à Pesquisa e bolsa de Iniciação Científica.

${ }^{2}$ Doutora em Educação pela Universidade Estadual Paulista (UNESP). Pós-Doutorado em Estudos de Mídia pela The Open University, Inglaterra. Professora da disciplina Comunicação, Educação e Tecnologia para os cursos de licenciaturas da Universidade Federal do Triângulo Mineiro, Brasil. E-mail: bujokas@uol.com.br.

${ }^{3}$ Mestre em TV Digital pela Universidade Estadual Paulista (UNESP), Campus de Bauru, Brasil. E-mail: marianacerigatto@hotmail.com.
} 
dade, qualidade e gosto. A experiência também mostrou as dificuldades estruturais que a cultura escolar estabelecida tem para pôr em prática atividades deste tipo.

Palavras-chave: mídia-educação; cinema; linguagem; Ensino Médio.

\begin{abstract}
Although the learning on media is not properly a new subject, it is a theme which has been gaining relevance within the Brazilian educational system. At the international level, the promotion of media literacy is a practice maybe as old as the means of communication themselves. With the rise of the new media, Educational paradigms and teaching materials have quickly changed, requiring a revision of concepts and a new position of the media studies in the school curriculum. According to this context, this paper elaborates a work proposal in tune with the paradigms of the British media-education (Hall, Whannel, Buckingham, Kress) and the new sphere of digital culture. Starting from movie trailers available on Youtube, we created reading and writing activities for High Schools, inside the area called "Codes, Languages and their Technologies", testing such activities in 20 students of a public school in the city of Bauru, State of São Paulo. The methodology consists of selecting trailers of popular movies from different genres and creating activities to dismantle the audiovisual text, explore the characteristics of language, think about the relationships of the text with the audience and evaluate the possible learning. The results suggest that the focus on the systematic analysis of language is a particularly productive way to reflect about questions on representation, identity, quality and taste. The experience also showed the structural difficulties faced by the established school culture to put into practice activities like these.
\end{abstract}

Keywords: media education; cinema; language; High School.

\title{
Por que mídia no currículo?
}

A ideia não é nova: aproximar os meios de comunicação da educação escolar é prática tão antiga quanto as próprias mídias (HALLORAN; JONES, 1986). Apesar disso, ainda hoje, pesquisas mostram que a apropriação crítica do discurso midiático em atividades educacionais não é prática que se concretizou.

Os argumentos que justificam (e renovam) a necessidade de incluir educação para a mídia no currículo escolar são conhecidos: 1. os meios de comu- 
nicação, em alguma de suas formas, ocupam posição central na vida pública de pessoas de todas as idades, em termos de trabalho, participação política, educação e entretenimento; 2. o teor das mensagens nunca é transparente, isto é, como em outras esferas discursivas, o conteúdo veiculado pelas mídias transmite valores e pontos de vista sectários, querendo parecer universais; 3. a participação social requer também pessoas hábeis para lidar com as mídias, que saibam, ao mesmo tempo, defender-se de efeitos nocivos e tirar proveito daquilo que lhes convém, como consumidoras e como cidadãs.

Um exame na base legal da educação brasileira sugere que a legitimação do estudo dos meios de comunicação está presente nos referenciais e parâmetros curriculares, tanto para o Ensino Fundamental quanto para o Ensino Médio. Ao focar a centralidade da análise e reflexão sobre a língua já nos anos iniciais do Ensino Fundamental, os PCN para a $1^{a}$ à $4^{\mathrm{a}}$ séries da área de Língua Portuguesa prescrevem que:

Uma prática fundamental de análise e reflexão sobre a língua, que tem relação com a produção oral e com a prática de leitura, é a recepção ativa: prática que, cada vez mais, torna-se uma necessidade, especialmente no que diz respeito aos textos veiculados pelos meios de comunicação de massa. (BRASIL, 1997, p. 54).

Já os Parâmetros Curriculares Nacionais para o Ensino Médio abordam o estudo da mídia em pelo menos duas oportunidades. Na área de Códigos, Linguagens e suas Tecnologias, o documento prevê, nas atividades de ensino de artes, ensinar o aluno a:

- Entender o impacto das tecnologias de comunicação e informação na sua vida, nos processos de produção, no desenvolvimento do conhecimento e na vida social;

$[\ldots]$

- Aplicar as tecnologias de comunicação e informação na escola, no trabalho e em outros contextos relevantes para a sua vida; (BRASIL, 2000a, p. 12).

O volume da área de Ciências Humanas e suas Tecnologias também prevê o uso dos meios de comunicação: 
No contexto escolar, especificamente, a própria organização curricular sob uma orientação interdisciplinar, explícita e consciente tanto para os educadores quanto para os estudantes, constitui uma oportunidade privilegiada para o desenvolvimento de competências associadas às tecnologias das Ciências Humanas. E o mesmo se pode dizer a respeito da utilização das tecnologias de informação e comunicação para a construção de redes informatizadas interativas ou a utilização das já existentes, a fim de propiciar a troca de informações ou o gerenciamento coletivo de projetos de estudo. (BRASIL, 2000b, p.17).

Neste contexto, duas habilidades básicas devem ser desenvolvidas nas aulas:

- Criticar, analisar e interpretar fontes documentais de natureza diversa, reconhecendo o papel das diferentes linguagens, dos diferentes agentes sociais e dos diferentes contextos envolvidos em sua produção.

- Produzir textos analíticos e interpretativos sobre os processos históricos, a partir das categorias e procedimentos próprios do discurso historiográfico. (BRASIL, 2000b, p. 28).

Ainda assim, mídia-educação não é assunto recorrente na sala de aula. Uma das razões para tal ausência talvez seja a falta de materiais didáticos específicos sobre o assunto, e essa lacuna é o ponto de partida para o presente artigo, que descreve a produção e o teste de um material pedagógico para ensinar leitura crítica da mídia para alunos do Ensino Médio, usando trailers de cinema e envolvendo leitura e escrita multimodais (KRESS, 2000), em sintonia com os referenciais internacionais de promoção da media literacy e com os referenciais curriculares para a área de Códigos, Linguagens e suas Tecnologias.

$\mathrm{O}$ objetivo geral do estudo foi produzir um material pedagógico que auxilie o estudante a compreender o modo como são criadas as convenções da linguagem cinematográfica no contexto institucional da indústria da cultura. Os objetivos específicos foram facilitar a criação de situações em que estudantes e professores pudessem refletir sobre as origens dos seus gostos e prazeres obtidos com o consumo de produtos midiáticos, promover atividades que estimulem a discussão em grupo, com o objetivo de construir uma inteligência coletiva sobre um assunto específico, além de mapear as habilidades necessárias para a formação dos professores que sejam hábeis em aplicar atividades de mídia-educação. A pesquisa foi financiada pela Fundação de Amparo à Pesquisa do Estado de São Paulo (Fapesp), entre 2008 e 2009, na forma de auxílio à pesquisa e bolsa de iniciação científica. 


\section{Síntese da fundamentação teórica Mídia-educação e abordagens pedagógicas}

Mídia-educação, leitura crítica dos meios, educomunicação, educação para a mídia e media literacy são alguns dos termos usados para caracterizar uma área interdisciplinar do conhecimento que se preocupa em desenvolver formas de ensinar e aprender aspectos relevantes da inserção dos meios de comunicação na sociedade. Assim, a "literacia em mídia" é o resultado esperado dessas ações pedagógicas, que envolvem, necessariamente, a compreensão crítica e a participação ativa.

O modo como são desenvolvidas e implementadas as ações pedagógicas para ensinar mídia varia de acordo com a concepção que os educadores e comunicadores têm dessa área que, conforme Green e Hannon (2007), transita entre dois extremos: o da fé cega na tecnologia (para quem a simples presença das mídias na escola, em si mesma, já é algo revolucionário e positivo) e o do pânico moral (para quem a cultura trazida pelas mídias é uma degeneração que deve ser combatida pela educação escolar).

Entre os extremos encontra-se uma série de posturas mais equilibradas, que, conforme Buckingham (2003), preocupa-se não em exaltar o potencial nem em "inocular contra", mas sim em preparar as pessoas para usar as mídias com mais proveito, tanto como consumidoras quanto como cidadãs.

De acordo com Halloran e Jones (1986), a abordagem inoculativa não é novidade e sempre caracterizou o uso das mídias na educação, desde os primórdios do cinema. Buckingham (2003) rastreia os argumentos dessas duas posições extremistas (fundamentando-se em Neil Postman e em Don Tapscott) e sugere um caminho equilibrado, que deveria ser seguido pelos educadores em mídias. O Quadro 1, na página seguinte, sintetiza as duas posturas.

$\mathrm{O}$ avanço da pesquisa na área tem mostrado que é cada vez mais difícil sustentar a ideia de mídia como direcionadora de opiniões, crenças e ideologias ou como vazia de valores culturais. Mas também não se trata de aderir à crença cega no potencial educativo dos meios de comunicação. Entre essas as duas posturas extremadas, o que Buckingham propõe é uma postura equilibrada que:

1. Reconheça a existência do fenômeno "poder da cultura de massa", mas o vê como algo fragmentado, especialmente por causa do desenvolvimento das novas tecnologias;

2. Considere pesquisas que mostram que as crianças são mais críticas e conscientes do que se supunha originalmente - aspecto que é notado, inclusive, pela indústria midiática; 


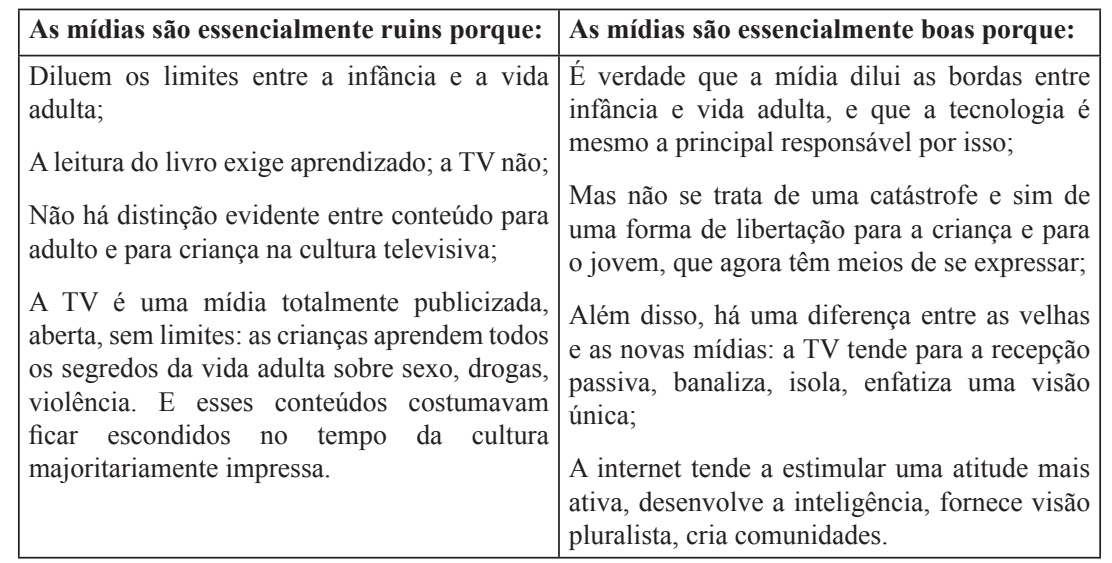

Quadro 1 - Postura moralista e postura cegamente otimista sobre o papel das mídias na vida e na educação de jovens.

3. Considere as mudanças que ocorreram no controle dos pais sobre os filhos - com a proliferação de canais, é cada vez mais difícil impedir que as crianças acessem conteúdos inadequados. O bloqueio, para ser efetivo deverá ser tão extenso que, na prática, poderá virar uma barreira ao acesso em geral. Uma saída prática é ter órgãos reguladores que saibam aconselhar consumidores e cidadãos - a educação para a mídia tem sido interpretada como uma etapa dessa tarefa de aconselhamento.

Buckingham (2003, p. 13) fala no surgimento de um novo paradigma para a mídia-educação (media literacy), chamado de "preparação para usar as mídias", que é fruto de experimentos realizados principalmente nos últimos 30 anos.

Adepta do mesmo paradigma, Tyner (1998) acredita que as formas eletrônicas não estão corroendo as mídias impressas como o livro e o jornal - e, consequentemente, corroendo a leitura -, mas estão modificando as formas como se lê e se escreve. Mudam-se as ferramentas de leitura, mudam-se também concepções sobre o que significa ser alfabetizado. Essas novas formas de leitura colocam em pauta questões sobre o modo como o público usa e dá sentido ao ato de ler - como seleciona e usa as unidades, elementos de um texto na sua forma, conteúdo e contexto.

Nesse sentido, segundo a autora, as formas digitais de comunicação são únicas porque têm o potencial de promover um colapso nas distinções entre os códigos e as convenções das linguagens oral, escrita, impressa e eletrônica e transformam todos esses códigos num compacto maleável de dados, permitindo 
a convergência de mídias em um só esquema audiovisual unificado. (TYNER, 1998).

Assim, uma abordagem contemporânea de leitura crítica da mídia deve saber aconselhar consumidores e cidadãos, tendo em vista a proliferação de canais que fazem com que crianças acessem conteúdos inadequados. "O novo paradigma não pretende agir como um escudo para proteger os jovens da mídia e conduzi-los para coisas melhores, mas sim torná-los habilitados a tomar decisões mais informadas, para seu próprio interesse." (BUCKINGHAM, 2003, p. 13).

Assim, os novos estudos de mídia-educação devem trazer à tona as seguintes questões:

1. Como identificar o que os estudantes sabem sobre mídia?

2. Como é que eles adquirem compreensão crítica ou de conceitos?

3. Como eles aprendem a usar as mídias para expressar a si mesmos e para se comunicar com os outros?

4. Como eles relacionam discurso acadêmico com suas próprias experiências como usuários de mídias?

5. Como podemos identificar e avaliar evidências do aprendizado?

6. Como podemos ter certeza de que a educação para a mídia faz diferença?

A posição mais equilibrada sobre a influência dos meios de comunicação na educação e na formação do jovem deve relembrar a ideia de McLuhan (2003) de que "o meio é a mensagem" e que, deste ponto de vista, podemos identificar, ao mesmo tempo, benefícios e malefícios no modo como as pessoas usam as mídias.

A televisão, por exemplo, habitua o receptor a privilegiar informações curtas, imediatas, fáceis de serem absorvidas, tais como um anúncio publicitário. Porém, como observa Belloni (2005), em um estudo que marcou época nos anos 1980, crianças e jovens em fase de formação que assistem à televisão adquirem certas habilidades, como conceitos de relações espaçotemporais, compreendem relações entre o todo e suas partes, identificam ângulos diferentes de tomadas de imagem.

$\mathrm{Na}$ Inglaterra, uma pesquisa liderada por Buckingham et al. (2005), encomendada pelo Office of Communications, mostrou que os jovens têm conhecimento razoável sobre como acessar conteúdos através das tecnologias. Entretanto, há indícios de que eles ainda são imaturos e inexperientes para identificar as estratégias de persuasão da publicidade vinda da TV e, principalmente, das novas mídias.

Segundo Buckingham (2003), o principal erro da abordagem inoculativa é tratar a mídia essencialmente como uma "força do mal", menosprezando, por exemplo, o prazer que a maioria de nós obtém assistindo a programas de comédia ou lendo tirinhas no jornal. Conforme Buckingham (2003): 
O ensino da mídia, claramente, precisa ser fundamentado numa profunda compreensão da experiência infantil com esses meios - uma experiência que a noção mais simplista de "influência" não explica adequadamente. [...]. O ensino sobre mídia deveria ser baseado na visão que concebe as crianças como produtoras ativas de significado, e que essa produção de significado é, fundamentalmente, uma atividade social.

Portanto, considerando o poder de atração que emana das mídias, as lições dos estudos em comunicação e a necessidade de educar para a preparação, podemos esboçar um perfil elementar do leitor crítico. Conforme Buckingham (2003), uma pessoa "literada" em mídia é capaz de ler conteúdos veiculados nos meios de comunicação da seguinte maneira:

1. Sabe construir uma narrativa em cima das imagens e textos;

2. Sabe fazer perguntas;

3. Sabe gerar hipóteses;

4. Sabe procurar respostas.

Essa forma de leitura crítica não ignora o prazer contido no conteúdo midiático e estimula a criação de expectativas, que exigem o uso de estratégias para estabelecer significados que são gerados no confronto com o "estoque" do conhecimento que já temos. Na sala de aula, trabalhar com hipóteses, perguntas e respostas pode ser uma atividade mais estimulante e produtiva do que a instrução explícita, baseada em leitura de conceitos teóricos e desgarrada da prática cotidiana do jovem com as mídias. Em certo sentido, esta abordagem também pode contribuir para a alfabetização em novas tecnologias, já que compreende o uso das mídias como leitura e escrita, num processo contínuo.

Portanto, mais do que uma inclusão no mundo tecnológico digital, a mídia-educação (ou media literacy) propõe encontrar formas de promover a educação específica para acessar, avaliar e produzir conteúdos, usando as diversas linguagens que a tecnologia digital permite. Agindo desse modo, a mídia-educação promove o diálogo da escola com as corporações de mídia e permite ao educando conhecer mecanismos de formatação do conteúdo. Não se trata de simplesmente menosprezar a indústria cultural, mas sim de mostrar que nela existem coisas boas e ruins.

\section{Técnicas pedagógicas para a mídia-educação}

Na prática, adotar a postura equilibrada da mídia-educação implica dominar certas técnicas pedagógicas específicas, que têm como objetivo básico 
mostrar ao educando que o sentido está na linguagem, tida como um fenômeno social marcado por disputas e controvérsias. Buckingham (2003) identifica seis técnicas mais comuns na área, a partir da experiência inglesa: análise textual, estudo do contexto, análise de conteúdo, estudo de caso, tradução (de um livro para um filme, por exemplo) e simulação-produção.

As análises textuais e de contexto têm como objetivo principal "fazer do familiar, estranho", para formar um ponto de vista crítico. Os alunos devem examinar padrões de linguagem e valores decorrentes do modo como as mensagens são organizadas. O estudo de caso e a tradução servem para explorar o modo como as mensagens midiáticas são produzidas e veiculadas. Finalmente, as atividades de simulação e produção priorizam a "escrita em mídia".

Para que o educando tenha condições de estudar a linguagem midiática, é necessário que compreenda conceitos vindos de áreas distintas, como a linguística, a análise do discurso, o design visual, a linguagem do corpo, a leitura do espaço e das sonoridades, os efeitos da montagem. Porém, essa tal ordem de conhecimentos é extensa e complexa, logo, inviável de ser ensinada nas estruturas comuns do currículo escolar. A saída, segundo Cope e Kalantzis (2000), é usar uma espécie de gramática funcional multimodal, que reúna elementos de diversas áreas do conhecimento para serem aplicados nas atividades de leitura e escrita verbais e não verbais. Em termos práticos, pode-se desenvolver projetos temáticos abrangentes, como o estudo das narrativas.

Assim, estudar a mídia a partir do conceito-chave de "narrativa", segundo Tilley (1991), muda o foco da crítica de fundo moralista para a crítica estrutural, que pode ser mais eficiente para promover o distanciamento necessário ao olhar crítico. Na prática, o educador parte de um filme preferido pelos jovens e oferece um modo sistemático para descobrir como é que o significado e os prazeres advindos da narrativa do filme trazem "embutidas" questões de representação e de poder simbólico.

Originalmente, a análise estrutural da narrativa vem da teoria da literatura (TODOROV, 2003) e da semiologia (BARTHES, 1992) e pode ser adaptada para o estudo da mídia na escola pela exploração de alguns conceitos-chave, segundo Tilley (1991). Entre eles estão:

1. Investigar como diferentes gêneros de narrativas cinematográficas estabelecem, elaboram e exercitam um problema: como o fazem os filmes policiais, os filmes de horror, as reportagens jornalísticas, os comerciais de TV; assistir a trailers de diferentes gêneros e reparar como cada um elabora os conflitos e quais são as pistas para sua formulação;

2. Investigar quem são os personagens principais, os secundários, os heróis, os vilões, os coadjuvantes. Traçar suas características físicas e morais e indagar quais valores esses personagens carregam. Avaliar qual é a função de cada personagem na história; 
3. Descrever os personagens que compõem a ordem inicial, os personagens que trazem o problema e prejudicam a ordem (e como a prejudicam), os personagens que trabalham para superar o problema (e como agem), os que ajudam os personagens que enfrentam o problema (e como ajudam), os que ajudam o personagem que provoca o problema (e como ajudam). Julgar valores implícitos nas ações dos personagens;

4. Refletir sobre as resoluções do herói no decorrer de uma narrativa, já que é o herói o maior responsável pelo restabelecimento da ordem; refazer o percurso de um herói ou heroína. Identificar de que forma o herói lidou com o problema para conquistar o restabelecimento da ordem e que implicações ideológicas tem essa ordem;

5. Estudar o papel do narrador: um observador onisciente, um personagem, um crítico da história, um defensor entusiasta da história. Identificar o modo como o narrador (evidente ou implícito) organiza os eventos da história.

Ao compreender o modo como a ordem é restabelecida numa história de ação americana ou como o final feliz é descrito numa novela, o estudante pode ser instigado a desvendar os meandros ideológicos das narrativas que ele gosta: incoerências, fatos importantes que foram negligenciados ou que passaram como sendo simplesmente naturais ou inevitáveis são postos em discussão, de forma pedagógica e sem rejeitar, de antemão, o gosto do aluno.

\section{Estudando as narrativas de trailers de cinema}

De acordo com Hall e Whannel (1964), até o seriado de TV mais pobre usa as técnicas de composição artística da linguagem audiovisual: roteirista e diretor precisam compor personagens e o desenrolar da ação, selecionar aspectos da vida que irão alimentar a trama, explorar alguns desses aspectos e comprimir outros, conferir uma textura humana ao enredo. O modo como esses filmes ou programas estabelecem relações com a realidade é que deve ser estudado. $\mathrm{Na}$ prática, essas relações se dão através do formato e do estilo.

Um exemplo típico dessas relações são as diferenças entre dois gêneros que têm em comum o uso da violência: o thriller de ação e o western. Para Hall e Whannel (1964), enquanto o thriller é um formato que explora a morte, o western é um filme que tem morte, mas é sobre outra coisa: sobre os grandes conflitos morais que todos nós enfrentamos e que, no enredo do filme, são desprovidos das ambiguidades da nossa vida moderna. Segundo os autores, essas diferenças estruturais são identificadas no modo como cada gênero utiliza os 
recursos do cinema. Assim, no western os enquadramentos são abertos, os movimentos de câmera são mais simples e as imagens são criadas para representar o bem contra o mal em termos mais simbólicos. No filme de ação, diversos enquadramentos repetem a exploração da dor, da agressão, do tiro e do sangue para gerar impacto psicológico.

Portanto, estudar os gêneros cinematográficos mais populares numa abordagem multimodal pode ser um caminho muito produtivo para tratar de questões mais amplas, como linguagem, representação e ideologia, que são temas centrais para a mídia-educação.

No cinema, a ideia de gênero se refere a um conjunto de códigos e convenções estabelecidos culturalmente e que são compartilhados pelo conjunto de consumidores (BRANSTON, 2006). Genericamente falando, esses códigos e convenções são formados por:

1. Elementos audiovisuais - atores conhecidos, cenários, estilos de câmera, iluminação, estilo de edição, música e efeitos;

2. Narrativas - clássica (formada por uma situação inicial de equilíbrio, que sofre uma ruptura e depois é reequilibrada de outra forma), inovadora (filmes com final aberto ou com falta de conflitos) e híbridas (estrutura clássica dentro de um musical, por exemplo);

3. Relações ideológicas - gêneros mais tradicionais tendem a ter valores conformistas, enquanto gêneros mais inovadores tendem a desafiar valores hegemônicos.

Assim, quando uma pessoa sabe identificar esses elementos e o modo como eles são organizados na forma e no estilo do filme, ela tem mais condições de avaliar os propósitos do autor, os valores e representações que estão em jogo e se torna uma usuária crítica do cinema. Leitores críticos, inclusive, sabem distinguir os propósitos de uma narrativa audiovisual, identificando propósitos para o filme e para o trailer, que é do filme derivado, mas tem uma linguagem própria.

Conforme Peruzzolo (2004), o trailer emprega elementos da narrativa cinematográfica e argumentos publicitários como recursos persuasivos e, assim, funda sua linguagem própria, a fim de estabelecer, estrategicamente, um contrato de leitura ou contrato de vidência, isto é, a tentativa de se consolidar um acordo com o espectador para que ele vá ao cinema assistir ao filme promovido pelo trailer. Segundo Peruzzolo (2004, p. 172):

[...] o enunciador, ao operar a construção de sua fala, institui - e também arquiteta - um sujeito para o qual a destina. De um lado, o sujeito que assume o papel de destinador, e que exerce o fazer persuasivo, e, de outro, o sujeito que assume o papel de destinatário, e a quem cabe a função interpretativa e a decisão do que fazer com a obra que acolheu. 
Em outras palavras, emissor e receptor devem aceitar um determinado conjunto de princípios e regras para que a troca, a permutação intertextual se torne possível. Trata-se de uma espécie de contrato de leitura, que visa estreitar laços entre enunciador e enunciatário por meio de conteúdos que pretendem servir como guia do olhar do telespectador. É nessa situação que o jogo publicitário-cinematográfico do trailer se torna concreto: há a explicitação dos papéis de produtor e consumidor e a transformação em práticas sociais dos valores afirmados na tela do cinema.

Enfim, este é o pano de fundo teórico que orientou a produção de um material didático para ensinar leitura crítica da mídia a partir de trailers de cinema. O material foi testado em 10 oficinas com duas turmas de 10 alunos do Ensino Médio de uma escola pública localizada no município de Bauru, Estado de São Paulo. As atividades foram realizadas no Laboratório de Mídia-Educação da Universidade do Sagrado Coração, o Midialab, durante um semestre letivo.

\section{Relato da experiência}

As oficinas foram realizadas uma vez por semana com cada turma, com quatro horas de duração cada. Ao todo, participaram 20 alunos do $1^{\circ}$ e $3^{\circ}$ anos do Ensino Médio. De um modo geral, as oficinas tinham dois objetivos: mostrar como a linguagem gera sentido e como o apelo é construído em cada gênero cinematográfico, em função das expectativas da audiência. Foram abordados termos técnicos do cinema, tais como ângulos, planos, montagem, sonoplastia, narrativa, gêneros etc.

A hipótese era que, ao se apropriar de elementos-chave da técnica e da simbologia própria do trailer de cinema, os estudantes estariam mais preparados para efetuar leituras críticas das mídias que eles usam cotidianamente. Assim, analisando a linguagem de trailers de quatro gêneros diferentes, refletindo sobre o modo como eles foram produzidos e que audiência cada filme pretendia alcançar, os alunos, aos poucos, iriam adquirir instrumentos cognitivos para examinar a linguagem audiovisual de uma perspectiva mais crítica. E capacidade crítica, do ponto de vista desse trabalho, é assistir a um trailer ou a um filme e conseguir identificar como ele foi feito, para que público e com quais objetivos. Dessa maneira, o leitor consegue emitir juízos de valor de forma mais criteriosa e informada.

Num segundo momento, depois da familiarização com a linguagem dos trailers, nos preocupamos em produzir conteúdo, aplicando o conhecimento conceitual: os alunos montaram seus próprios roteiros, saíram a campo para captar imagens, fizeram experiências com montagens. Em cada cena, nós os 
estimulamos a aplicar elementos de cinematografia que havíamos observado nas atividades de leitura. Também trabalhamos com desenho para storyboard, transpondo assim a linguagem do audiovisual para linguagem gráfica impressa, e com crítica de filme, usando a linguagem escrita para sintetizar o aprendizado. As produções foram sendo publicadas em blogs individuais. O quadro 2, a seguir, sintetiza objetivos e procedimentos de cada uma das 10 oficinas:

\begin{tabular}{|c|c|c|}
\hline & OBJETIVO & ATIVIDADES REALIZADAS \\
\hline OFICINA 1 & $\begin{array}{l}\text { Mostrar como } \\
\text { planos e ângulos } \\
\text { específicos são } \\
\text { usados para ge- } \\
\text { rar determinados } \\
\text { tipos de sentido, } \\
\text { independente- } \\
\text { mente do gênero } \\
\text { do filme. }\end{array}$ & $\begin{array}{l}\text { - Conversa inicial sobre os filmes a que os alunos assistiram recen- } \\
\text { temente, se gostaram ou não e por quê; } \\
\text { - Discussão sobre gosto e gênero e sobre linguagem típica de cada } \\
\text { gênero, a partir de questões como "qual é a diferença entre filme de } \\
\text { ação e drama?"; } \\
\text { • Apresentação de um webvideo sobre ângulos e planos no cinema"; } \\
\text { - Estudo de quatro trailers de gêneros diferentes: "Piratas do Cari- } \\
\text { be" (aventura), "Jogos Mortais" (terror), "American Pie" (comédia) } \\
\text { e "Zuzu Angel" (drama), a partir de uma ficha com questões como: } \\
\text { "que tipo de sentimento cada gênero provoca?", "O que no filme } \\
\text { desperta tais sentimentos?", "Qual é a intenção do diretor ao esco- } \\
\text { lher determinado plano ou ângulo ao filmar uma cena?"; } \\
\text { - A atividade foi feita com apoio de um material produzido em Po- } \\
\text { wer Point com a decupagem dos trailers; } \\
\text { - Ao final, registraram o aprendizado em blogs pessoais". }\end{array}$ \\
\hline OFICINA 2 & $\begin{array}{l}\text { Aplicar conheci- } \\
\text { mentos sobre ân- } \\
\text { gulos e planos, } \\
\text { num exercício } \\
\text { prático de pro- } \\
\text { dução. }\end{array}$ & $\begin{array}{l}\text { - Noções de roteiro: storyline e script, a partir de uma proposta } \\
\text { previamente definida: fazer um pequeno filme que mostra um } \\
\text { estudante chegando atrasado para a aula, ansioso porque precisa } \\
\text { entregar um trabalho e, quando chega, percebe que esqueceu o } \\
\text { caderno com o trabalho em casa; } \\
\text { - O filme foi organizado em nove sequências. A primeira tarefa } \\
\text { foi planejar as cenas de cada sequência, indicando no script quais } \\
\text { planos e ângulos seriam mais adequados para expressar o conteúdo } \\
\text { ali proposto (aluno chega de ônibus, olha o relógio e percebe que } \\
\text { está atrasado, segue em passo rápido em direção à universidade } \\
\text { etc.); } \\
\text { - Com o script em mãos, o grupo partiu para a captação de cenas. }\end{array}$ \\
\hline OFICINA 3 & $\begin{array}{l}\text { Observar como } \\
\text { o tipo de som } \\
\text { muda o "clima } \\
\text { da cena". }\end{array}$ & $\begin{array}{l}\text { - Estudo da influência do som na compreensão da mensagem, a } \\
\text { partir de um programa de rádio } 0^{6} \text { e de uma apresentação em Power } \\
\text { Point sobre o conceito de sonoplastia (trilha sonora, diálogos e } \\
\text { narração, efeitos sonoros naturais e artificiais); } \\
\text { - Análise da sonoplastia de cada trailer, ouvindo o som, sem } \\
\text { imagem, para identificar o estilo da trilha sonora, tom da voz do } \\
\text { narrador, diálogos e efeitos; } \\
\text { - Estudo das imagens e dos sons, de cada trailer, para identificar } \\
\text { o momento em que diferentes recursos surgem e qual efeito têm } \\
\text { sobre a imagem; } \\
\text { - Aplicação do conhecimento no planejamento da sonoplastia para } \\
\text { as sequências gravadas na oficina anterior. }\end{array}$ \\
\hline
\end{tabular}

${ }^{4}$ Disponível em: $<$ http://tiny.cc/planoseangulos $>$.

${ }^{5}$ A lista de blogs está disponível em: <http://tiny.cc/blogsdosalunos $>$.

${ }^{6}$ Disponível em: <http://tiny.cc/programaderadio $>$. 
Quadro 2 - Continuação.

\begin{tabular}{|c|c|c|}
\hline OFICINA 4 & $\begin{array}{|lr|}\text { Aplicar } & \text { os } \\
\text { conceitos } & \text { fun- } \\
\text { damentais } & \text { de } \\
\text { sonoplastia } & \text { na } \\
\text { produção de } & \text { um } \\
\text { filme. } & \end{array}$ & $\begin{array}{l}\text { - Análise da animação feita pela Walt Disney para a música } \\
\text { "Rhapsody in Blue", de George Gershwin, para o filme "Fantasia"; } \\
\text { - Análise da música, sem imagem, a partir da pergunta: "que tipo de } \\
\text { sentimento cada parte da música provoca?"; } \\
\text { - Escolha de trechos da música que servissem à sonorização do } \\
\text { filme, para gerar momentos de expectativa, calma, relaxamento, } \\
\text { diversão etc.; } \\
\text { - Produção de diálogos e seleção de efeitos sonoros para as } \\
\text { sequências; } \\
\text { - Início da edição, sonorizando as sequências separadamente, } \\
\text { usando o software Windows Movie Maker. }\end{array}$ \\
\hline OFICINA 5 & $\begin{array}{l}\begin{array}{lr}\text { Conhecer } & \text { os } \\
\text { efeitos da } & \text { mon- } \\
\text { tagem }\end{array}\end{array}$ & $\begin{array}{l}\text { - Análise de dois filmes antigos: "O grande engolidor" (James } \\
\text { Williamson, 1901) e "A lupa da vovó" (George Albert Smith, 1900) } \\
\text { que, embora sejam muito simples, já aplicavam técnicas de corte e } \\
\text { junção; } \\
\text { • Estudo do conceito e de técnicas básicas de montagem; } \\
\text { - Produção de um exercício prático: um filminho em que um aluno } \\
\text { olha para a tela do computador, com cara de entediado. De repente, } \\
\text { tem uma ideia, sai correndo pelo corredor da biblioteca, dá um salto } \\
\text { e cai na grama do jardim, com um livro na mão. O corte entre o } \\
\text { salto para cima, na biblioteca, e a aterrissagem, no jardim, foi o } \\
\text { objeto da experimentação com a montagem. }\end{array}$ \\
\hline OFIC & $\begin{array}{l}\text { Fazer a monta- } \\
\text { gem do filme } \\
\text { sobre o estudan- } \\
\text { te que esquece o } \\
\text { caderno (nove se- } \\
\text { quências grava- } \\
\text { das na oficina 2) } \\
\end{array}$ & $\begin{array}{l}\text { - Conferir a sonoplastia das sequências e juntá-las, usando recursos } \\
\text { de montagem, como efeitos gráficos e som; } \\
\text { - Finalizar o filme, colocando créditos. Com essa atividade, fechou- } \\
\text {-se o ciclo do ler e escrever usando a linguagem audiovisual }{ }^{8} \text {. }\end{array}$ \\
\hline OFICINA 7 & $\begin{array}{l}\text { Compreender em } \\
\text { que medida a es- } \\
\text { trutura narrativa } \\
\text { se desenvolve } \\
\text { em função das } \\
\text { expectativas do } \\
\text { público }\end{array}$ & $\begin{array}{l}\text { - Identificar o começo, o meio e o fim em narrativas diversas, tais } \\
\text { como piadas, tirinhas jornal e trailers de filmes; } \\
\text { - Identificar as três fases da situação narrativa: o começo (situação } \\
\text { de normalidade), meio (desenrolar do conflito) e fim (solução para } \\
\text { o conflito); } \\
\text { - Identificar a estrutura narrativa nos quatro trailers analisados } \\
\text { anteriormente, usando um guia de estudos e a decupagem das cenas } \\
\text { em Power Point; } \\
\text { - Os alunos deveriam explicar o que acontecia na narrativa que os } \\
\text { fazia acreditar que aquele ponto era a passagem do início para o } \\
\text { meio: um diálogo? Um efeito sonoro? Um conteúdo da cena? Um } \\
\text { recurso de montagem?; } \\
\text { - Identificar os mesmos recursos no filme produzido pelo grupo. }\end{array}$ \\
\hline
\end{tabular}

${ }^{7}$ Disponível em: <http://www.youtube.com/user/midialab $>$.

${ }^{8}$ Disponível em: $<$ http://www.youtube.com/user/midialab $>$. 
Quadro 2 - Continuação.

\begin{tabular}{|c|c|c|}
\hline OFICINA 8 & $\begin{array}{l}\text { Investigar como } \\
\text { o público in- } \\
\text { fluencia e é in- } \\
\text { fluenciado pelos } \\
\text { trailers }\end{array}$ & $\begin{array}{l}\text { - Usando uma ficha com uma lista de expectativas que o público } \\
\text { pode ter conforme o gênero do filme (rir, assustar-se, emocionar-se, } \\
\text { refletir sobre algum assunto etc.), formular hipóteses sobre o perfil } \\
\text { do público de gêneros específicos de filmes, tais como comédia, } \\
\text { horror, cult etc.; } \\
\text { - Identificar quais aspectos do conteúdo e da linguagem do filme } \\
\text { indicam que aquele gênero satisfaz aquela expectativa; } \\
\text { - Compartilhar com os colegas as expectativas próprias em relação } \\
\text { ao cinema. }\end{array}$ \\
\hline OFICINA 9 & $\begin{array}{l}\text { Planejar uma es- } \\
\text { trutura narrativa, } \\
\text { em função de } \\
\text { um público e de } \\
\text { um gênero espe- } \\
\text { cífico }\end{array}$ & $\begin{array}{l}\text { - Em uma ficha com } 13 \text { opções de storylines envolvendo mocinho, } \\
\text { mocinha, vilão e vilã, identificar a qual gênero pertencia cada } \\
\text { storyline e por quê; } \\
\text { - Alterar a estrutura narrativa do conto da Rapunzel: como } \\
\text { continuar e terminar a história se fosse do gênero horror? Comédia? } \\
\text { Aventura?; } \\
\text { - Desenhar um storyboard planejando as cenas dos pontos-chave da } \\
\text { história modificada, pensando em planos e ângulos. }\end{array}$ \\
\hline OFICINA 10 & $\begin{array}{l}\text { Elaborar uma } \\
\text { crítica de filme }\end{array}$ & $\begin{array}{l}\text { - Estudo da estrutura de uma crítica feita ao filme "Central do } \\
\text { Brasil". O texto foi marcado com cores diferentes para localizar o } \\
\text { resumo da história, o apelo do filme, a descrição dos personagens } \\
\text { e a opinião do autor; } \\
\text { - Localização dos elementos da linguagem estudados nas oficinas e } \\
\text { comentados no texto; } \\
\text { - Estudo de pequenos comentários feitos na coluna de programação } \\
\text { de TV em jornais: os alunos deveriam sublinhar a opinião do autor } \\
\text { sobre o filme e separá-la da informação. Daí, deveriam interpretar se } \\
\text { a crítica era positiva ou negativa e em quais palavras ou expressões } \\
\text { eles tinham as pistas para identificar a posição do autor; } \\
\text { - Elaborar uma crítica do trailer do filme "Jogos Mortais", que foi } \\
\text { um dos estudados nas oficinas, usando uma ficha com itens básicos } \\
\text { para uma crítica; } \\
\text { • Elaborar uma crítica de trailer de livre escolha. }\end{array}$ \\
\hline
\end{tabular}

Quadro 2 - Síntese das oficinas.

\section{Resultados}

Foram avaliados os exercícios produzidos na forma de fichas de atividades, o conteúdo produzido em vídeo, os registros dos blogs e as gravações em vídeo das oficinas. A análise dos dados foi pautada por três categorias:

1. Habilidades que cada grupo possui para lidar com as linguagens multimodais;

2. Critérios usados para julgar o teor das mensagens midiáticas;

3. Manifestações espontâneas de cada participante. 


\section{O quadro 3, a seguir, reproduz alguns dos textos registrados nos blogs} dos alunos:

"Estudando cinematografia. Hoje no curso aprendi a analisar trailers. Cada filme tem um gênero diferente, como comédia, terror, drama, ficção e etc. Vi vários tipos de ângulos de filmagem. Acho que agora já posso 'ler' trailers de filmes um pouco melhor."

Bruno Rafael Paladini Galvão - Aluno do terceiro ano do Ensino Médio

(Retirado do blog http://midialabbrunorafaelpaladinigalvao.zip.net/)

"Eu aprendi sobre os planos e ângulos que os cineastas usam no cinema. E os planos são: plano geral, aberto, americano, médio, close e super close. E os ângulos são panorâmica, travelling, chicote, zoom in, zoom out, plongée e contre-plongée."

Beatriz Cristina - Aluna do primeiro ano do Ensino Médio

(Retirado do blog http://midialabbeatrizcristinafranciscodasilva.zip.net/)

"Hoje eu aprendi como é um curta-metragem, como são as filmagens, as formas que eles trabalham com as câmeras, como são colocadas as ideias no script. Adorei a aula de hoje espero cada vez mais me adaptar a esse curso interessante".

Ana Cláudia Felipe - Aluna do terceiro ano do Ensino Médio

(Retirado do $b \log$ http://midialabanaclaudiafelipedasilva.zip.net/)

"Hoje aprendi a ser cameraman e a fazer um filme, como mexer com script, com as sequências que compõem um filme, sobre os planos, ângulos e muitas outras coisas, espero que gostem do meu blog". Guilherme Borges - Aluno do terceiro ano do Ensino Médio

(Retirado do blog http://midialabguilhermeborgesafonsomendoca.zip.net/)

"Hoje aprendemos a importância do som. Aprendemos que ele é muito importante para um vídeo. Pois é ele quem complementa qualquer sentido que o vídeo possa fazer. Nos vídeos aparecem 3 tipos de som: - trilha sonora - diálogos - efeitos sonoros".

Beatriz Cristina - Aluna do primeiro ano do Ensino Médio

(Retirado do $b \log$ http://midialabbeatrizcristinafranciscodasilva.zip.net/)

"Hoje falamos sobre som e impactos postos em filmes e filmagens... que os sons podem despertar uma reação em quem tá assistindo..."

Franciele Cristina Cuistódio - Aluna do terceiro ano do Ensino Médio

(Retirado do $b \log$ http://midialabfrancielecristinadonascimentocustodio.zip.net/)

"Hoje aprendi a editar um filme, parte por parte, sonorização, sequências, aprendi a cortar os filmes para não ficar as partes mal feitas, a colocar os efeitos sonoros"

Guilherme Borges - Aluno do terceiro ano do Ensino Médio

(Retirado do blog http://midialabguilhermeborgesafonsomendoca.zip.net/)

"Hoje eu aprendi como são feitas as edições de filmes, ela serve para colocar áudio, músicas, sonorizar vídeos. Muito interessante essas edições de filme, cada vez mais eu adoro esse curso".

Ana Cláudia Felipe - Aluna do terceiro ano do Ensino Médio

(Retirado do $b \log$ http://midialabanaclaudiafelipedasilva.zip.net/)

"Montagem: é a junção de cenas. Por exemplo, quando vamos fazer um filme gravamos continuamente uma cena, depois dividimos ela em várias partes e remontamos da forma que desejamos. Isso é montagem. A montagem serve para criar efeitos na cena, manipulando a realidade. Hoje eu fiz a minha própria montagem. Usei algumas músicas e alguns efeitos que achei mais adequados às cenas e cortei algumas partes que não faziam muito sentido."

Jéssica Pestana Garcia - Aluna do primeiro ano do Ensino Médio

(Retirado do blog http://midialabjessicapestanagarcia.zip.net/) 
Quadro 3 - Continuação.

"Na aula de hoje estamos aprendendo montagem.

1: Montagem:é a junção de cenas que são filmados em lugares separados

2: Montagem serve para manipular a realidade fazer coisas que na vida real não existe. Dá pra colocar músicas efeitos.

3: Meu vídeo foi feito assim: cortei as partes que não aparecia nada coloquei musicas e efeitos e transições de vídeo."

Beatriz Cristina - Aluna do primeiro ano do Ensino Médio

(Retirado do blog http://midialabbeatrizcristinafranciscodasilva.zip.net/)

"Estrutura e narrador: Na estrutura narrativa eu aprendi os três momentos da estrutura:1. Situação de normalidade, 2.Situação de conflito, solução do conflito. Eu aprendi que tem três tipos de narrador: um é o personagem que conta a história o outro é o impessoal que aparece sons de vozes e também através de legendas, o ausente é quando não tem narração nenhuma".

Guilherme Henrique - Aluno do terceiro ano do Ensino Médio

(Retirado do $b \log$ http://midialabguilhermehenrique.zip.net/)

"Hoje eu aprendi a fazer produção de storyboard, como são feitos os filmes em outros gêneros, como são feitos os scripts. Foi muito interessante a aula de hoje, adorei saber que existe forma de mudar o gênero de um filme".

Ana Cláudia Felipe - Aluna do terceiro ano do Ensino Médio

(Retirado do $b \log$ http://midialabanaclaudiafelipedasilva.zip.net/)

"Bom, hoje eu aprendi a fazer critica de filmes, a ver cenas de filme: se favorecem ou desfavorecem o filme; sonorização: se caiu bem no filme e com o gênero que foi posto pelo diretor; se o filme chama atenção do público-alvo. Aprendemos também a diferenciar a data, da opinião e do resumo quando já estão publicados. Na minha opinião, o desenvolvimento dessa atividade foi meio difícil. foi fácil sim, quando era para nos criticarmos as críticas dos outros, mas passou a ficar dificil quando foi para nós fazermos a nossa própria crítica..."

Franciele Cristina Cuistódio - Aluna do terceiro ano do Ensino Médio

(Retirado do $b \log$ http://midialabfrancielecristinadonascimentocustodio.zip.net/)

"Eu aprendi que a crítica de cinema é muito importante para avaliar se o diretor soube escolher os personagens, a trilha sonora etc. Para expressar opinião o crítico usa adjetivos. E aprendi também como se estrutura uma crítica".

Guilherme Henrique - Aluno do terceiro ano do Ensino Médio

(Retirado do $b \log$ http://midialabguilhermehenrique.zip.net/)

Quadro 3 - Registros dos blogs.

A análise dos dados resultantes das oficinas sugere os seguintes resultados:

1. De um modo geral, os alunos ficam motivados e se engajam na realização das atividades;

2. A maioria tem facilidade para compreender conceitos técnicos e identificar recursos de linguagem quando analisam um texto audiovisual;

3. Entretanto, na maioria das vezes em que são solicitados a emitir juízos de valor, eles têm dificuldades para identificar questões de representação (se determinados comportamentos ou aparências são valorizados ou desvalorizados, como e por que, por exemplo) e tendem a repetir sempre as mesas palavras: legal, divertido, chato; 
4. Observando sistematicamente as gravações em vídeo, percebemos que o grupo tinha sempre muito receio em manifestar a opinião própria, tendência que se repetia na produção de textos para os blogs. Em outras palavras, os alunos parecem não ter familiaridade com o debate de ideias e se sentem muito inseguros quando precisam fazer uma crítica.

5. O grupo demonstrou facilidade para fazer exercícios de caráter mais técnico, como, por exemplo, identificar os planos cinematográficos presentes num trailer ou decidir que tipo de plano seria mais adequado para mostrar a preocupação de uma pessoa que se aproxima de um lugar específico. Mas, quando são solicitados a criar diálogos, títulos de filmes, finais inesperados, enfim, exercícios de criatividade, eles não demonstram a mesma capacidade - ou não se sentem seguros para expressar suas ideias.

\section{Considerações finais}

Durante a realização das oficinas, por diversas vezes vivenciamos os típicos problemas relativos à pouca familiaridade que os alunos têm com a prática de escrever textos. Além dos erros de ortografia e gramática, percebemos que os textos saíam um pouco infantis para a idade deles.

Para amenizar o problema da ortografia, passamos a usar o corretor do Open Office antes de publicar. Também passamos a incluir a leitura de jornais e revistas antes de iniciar as atividades. A maioria manifestava interesse, lia e comentava as notícias - em especial diversidades e esportes. Nas seis oficinas em que levamos jornais e revistas, notamos que os alunos olhavam as fotos do caderno de política, mas não se detinham nas notícias.

Essa vivência nos levou a tecer algumas considerações. Em primeiro lugar, nos indagamos onde começa essa história de que o aluno não sabe escrever porque não lê, e, porque não lê, não desenvolve o hábito da leitura e da escrita, terminando o Ensino Médio com habilidades aquém do esperado. Não é nosso objetivo aqui discutir questões sobre problemas de aprendizagem, mas nossa pequena experiência sugere que, independentemente do tipo de texto, são fundamentos muito elementares da linguagem que não estão sendo considerados nas atividades escolares. Presenciamos uma cena no Midialab que talvez mereça ser melhor analisada. Decidimos não interferir nos erros dos textos dos alunos 
- ao menos não de modo incisivo, para que eles não se sentissem intimidados ao escrever. Só ajudávamos quem nos solicitava. Numa oficina, recebemos uma nova monitora, que não tinha acompanhado o histórico da produção de textos para os blogs. Talvez por isso ela foi um pouco incisiva, dizendo aos alunos que eles cometiam muitos erros de português, ao que um dos alunos respondeu: "É assim que a gente escreve. Se você não quiser, não lê".

Essa situação nos levou a pensar no seguinte: é claro que os alunos ficam - de um jeito ou de outro - sabendo das notícias que circulam na mídia (e, consequentemente, circulam entre professores e alunos) sobre a falta de qualidade das escolas públicas, em contraste com a qualidade da maioria das escolas particulares. Quando uma escola pública alcança um nível mínimo de qualidade, vira notícia de destaque no jornal (notícia que foi publicada nos dias em que levamos jornais para o Midialab). Esses alunos já se sentem diminuídos por uma série de marginalizações: não têm o mesmo acesso às tecnologias, aos bens de consumo, ao aprendizado de uma língua estrangeira. Ser, de alguma forma, discriminado por não estudar em uma escola boa deve doer na alma de um adolescente. Talvez a rejeição ao aprendizado da leitura e da escrita seja um mecanismo de autodefesa: desvalorizar algo que não se sabe pode ser uma saída para não sofrer por não sabê-lo.

Observando as manifestações espontâneas nos registros em vídeo, percebemos que os alunos gostam da escola, mas não gostam de práticas culturais presentes ali dentro. Ao menos no grupo com o qual convivemos por quatro meses, a queixa é a de que os professores são extremamente críticos quando se referem às dificuldades com a leitura e a escrita: a escola ensina normas e nós ensinamos comunicação. Essa pareceu ser uma abordagem completamente nova para o grupo, embora tenhamos tratado de habilidades cotidianas, fruto da nossa experiência diária com as mídias.

Enfim, nossa experiência trouxe à tona um problema difuso, porém significativo para compreender as questões de ensino e aprendizagem da língua, seja nas modalidades escrita, falada ou multimodal: no fundo, ler e escrever envolve questões de caráter cultural, conflito de identidades e disputa de poder simbólico entre professores e alunos. Enfrentar essas questões requer o desenvolvimento de habilidades de análise crítica, diálogo, segurança para o debate, enfim, de comunicação. Nossa pequena experiência mostrou que o foco na linguagem dos conteúdos midiáticos é um ponto de partida viável e produtivo. Mas que, infelizmente, ainda não cabe na cultura da maioria das escolas, apesar do interesse dos alunos. 


\section{REFERÊNCIAS}

BARTHES, R. S/Z. Rio de Janeiro: Nova Fronteira, 1992.

BELLONI, M. Luiza. O que é mídia-educação. Campinas: Autores Associados, 2005.

BRASIL. Secretaria de Educação Fundamental. Parâmetros Curriculares Nacionais: Língua Portuguesa, $1^{\mathrm{a}}$ à $4^{\mathrm{a}}$ séries. Brasília, 1997.

. Secretaria de Educação Fundamental. Parâmetros Curriculares Nacionais

(Ensino Médio): Parte II - Códigos, Linguagens e suas Tecnologias. Brasília: 2000a.

. Secretaria de Educação Fundamental. Parâmetros Curriculares Nacionais

(Ensino Médio): Parte IV - Ciências Humanas e suas Tecnologias. Brasília: 2000b.

BRANSTON, G. Understanding genre. In: GILLESPIE, M.; TONYBERR, J. Analyzing media texts. Milton Keynes: Open University Press, 2006.

BUCKINGHAM, David. Media education - literacy, learning and contemporary culture. Cambridge: Polity Press, 2003.

et al. The media literacy of children and young people: a review of the research literature on behalf of Ofcom. Londres: Office of Communications, 2005.

COPE, Bill; KALANTZIS, Mary. Multiliteracies - Literacy learning and the design of social futures. Londres: Routledge, 2000.

GREEN, Hannah; HANNON, Celia. Their space - Education for a digital generation. Londres: Demos, 2007.

HALL, Stuart; WHANNEL, Paddy. The popular arts. Londres: Hutchinson Educational, 1964.

HALLORAN, J. D.; JONES, M. Learning about media: communications and society. Paris: UNESCO, 1986. (paper).

KRESS, Gunter. Multimodality. In: COPE, Bill; KALANTZIS, Mary. Multiliteracies Literacy learning and the design of social futures. Londres: Routledge, 2000.

McLUHAN, M. Os meios de comunicação como extensões do homem. São Paulo: Cultrix, 2003.

PERUZZOLO, Adair C. Elementos de semiótica da comunicação. Bauru: EDUSC, 2004.

TYNER, K. Literacy in a digital world. Mahwa: Lawrence Erlbaum, 1998.

TILLEY, A. Narrative. In: LUSTED, D. (Org.). The Media Studies Book - A Guide for Teachers. Londres: Routledge, 1991.

TODOROV, T. As estruturas narrativas. São Paulo: Perspectiva, 2003.

Texto recebido em 24 de fevereiro de 2010 .

Texto aprovado em 26 de dezembro de 2010. 